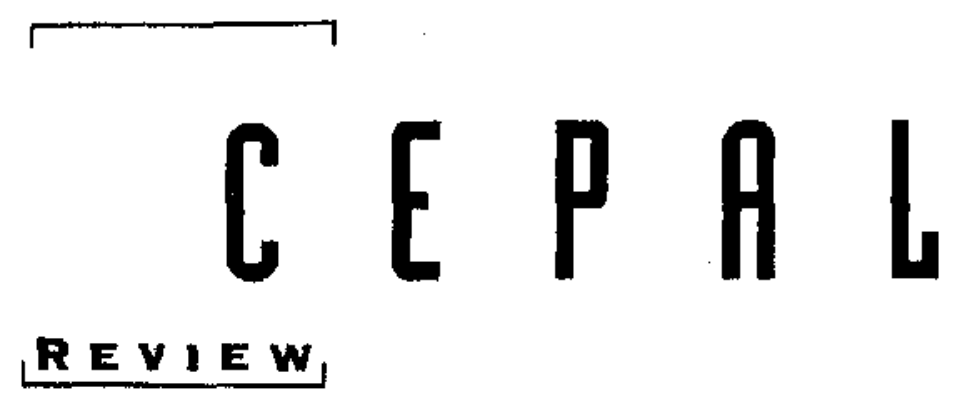

\author{
NUMEEF 65 \\ AUQUST 1998 \\ SANTIAGO, CHILE \\ O S CA ALTIMIA \\ Director of the Review \\ EUGENIO LAHEAA \\ Technical Secretary
}

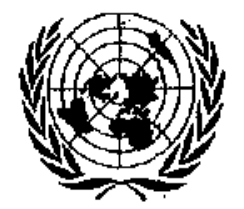


Income distribution, poverty and social expenditure In Latin Amerlca

José Antonio Ocampo

Military expenditure and development in Latin America

Eugenio Lahera and Marcelo Ortuzar

Growth, dlstrlbutive justice and social policy

Andrés Solimano

Equity, forelgn investment and International competitiveness

Adolfo Figueroo

Tensions in Latin American structural adjustment:

allocatlon versus distribution

Daniel M. Schydlowsky

Compethliveness and labour regulations

Luis Beccaria and Pedro Galín

Latin American femilles: convergences and divergences in models and pollcles

Irma Arriagada

Free trade agreements and female labour: the Chilean sltuation

Alicia Frohmann and Pilar Romaguera

Macroeconomic trends in Paraguay from 1989 to 1997:

consumptlon bubble and financial crisis

Stephane Straub

The strategies pursued by Mexican firms in their efforts

to become global players

Alejandra Salas-Porras

Pegulating the private provision of drinking water and sanitation services

Terence R. Lee and Andrei S. Jouraviev

Quallty management promotion to Improve competitiveness

Hessel Schuurman

Recent ECLAC publlcations 


\section{Free trade agreements and female labour: the Chilean situation}

\section{Allcia Frohmann Pilar Aomaguera**}

\footnotetext{
* Research professor. FLACSO-Chile.

** Professor in the Department of Industrial Engineering, University of Chile.
}

This article analyses the relations between economic integration processes, enaployment and equality of opportunities between men and women. To this end, the case of Chile is considered, where simultaneous processes of internationalization of the economy, the pursuit of economic integration agreements and the growing incorporation of women into the labour force are taking place. The relation between integration agreements and the labour situation of women deives from three factors. Firstly, the new trade flows affect enployment and wages, and there may be a differential effect by sex if the female labour force is concentrated in particular. sectors of production. Secondly, free trade agreements may explicitly incorporate items of labour legislation concerning women. Finally, the different labour laws and working conditions in countries entering into integration agreements have given rise to accusations of social dumping by developed countries against developing nations. Section $I$ of the article analyses the effect of trade agreements on employment and wages and describes the situation of the female labour market in Chile. Section II looks at the provisions of trade agreements regarding the female labour force and summarizes the arguments put forward about social dumping and the way this relates to legislation concerning women. Section III analyses the instruments which could be used to regulate the labour and social impacts of integration on the women's labour market. Finally, section IV presents some concluding comments. 


\section{I}

\section{Labour effects of trade agreements}

The increase in trade flows due to economic integration processes is leading to an intrasectoral and intersectoral reallocation of physical and human resources. Consequently, the integration of Chile into a trade agreement should affect sectoral levels of employment and wage differences between different sectors of production.

This section looks at the effects that the incorporation of Chile into a trade agreement like NAFTA could have on the women's labour market. Basically, it sets out some features of female employment in the Chilean economy and then goes on to review previous studies which have quantified the impact of free trade agxeements on employment and wages.

\section{The labour stituation of women in the Chilean economy}

Chilean women have been playing an increasing part in the labour market in recent years. The main features of this situation have been i) an increase in the rate of female participation; ii) a rate of participation which is still low in spite of the upward trend of recent years; iii) concentration of women's activities in certain sectors and occupations; iv) significant differences in wages between men and women, and v) the fact that the economic sectors in which the female employment is concentrated are likely to be "sensitive" to a free trade agreement.

The growing incorporation of women into the world of work is directly reflected in female rates of participation (see Mizala and Romaguera, 1996), which have risen from close to $25 \%$ in the mid-1970s to nearly $34 \%$ in 1995 (table 1 ).

The increase in female participation is a worldwide phenomenon which is linked with economic growth, development, cultural changes, and changes in the standards of living which accompany these processes, especially women's greater control over their own reproductive capacity.

[ This article is partly based on a report prepared for the Chilean National Women's Service (SERNAM). The authors wish to acknowledge the support received from the Chilean Scientific and Technological Development Fund (FONDECYT), Project No. 1960705.
TABLE 1

Chile: Rates of labour force particlpation, by gender, 1978-1995

\begin{tabular}{llll}
\hline Year & Total & Men & Women \\
\hline 1976 & 47.1 & 70.2 & 25.2 \\
1977 & 45.9 & 69.5 & 23.6 \\
1978 & 48.5 & 71.2 & 27.1 \\
1979 & 47.3 & 69.7 & 26.1 \\
1980 & 48.4 & 70.3 & 27.6 \\
1981 & 47.8 & 69.9 & 26.8 \\
1982 & 47.2 & 68.3 & 27.4 \\
1983 & 47.5 & 68.0 & 28.3 \\
1984 & 48.1 & 68.9 & 28.7 \\
1985 & 51.9 & 74.2 & 30.5 \\
1986 & 50.9 & 73.5 & 29.6 \\
1987 & 51.1 & 73.8 & 29.7 \\
1988 & 52.5 & 75.2 & 31.2 \\
1989 & 53.0 & 75.8 & 31.6 \\
1990 & 52.8 & 75.1 & 31.8 \\
1991 & 52.6 & 75.2 & 31.3 \\
1992 & 53.8 & 75.5 & 33.4 \\
1993 & 55.3 & 77.0 & 34.9 \\
1994 & 55.2 & 76.6 & 35.0 \\
1995 & 53.9 & 75.2 & 33.9 \\
\hline
\end{tabular}

Source: National Institute of Statistics (INE), Survey for the October-Decentuber quarter.

On the basis of international comparisons, however, it may be concluded that the level of female labour participation in Chile is still low and it is therefore reasonable to expect that there will be an ongoing tendency towards growing incorporation of women into the world of work. It should be noted that the rate of female participation in Chile is low not only compared with the developed countries but also compared with the recently developed Asian countries such as South Korea and Singapore, where this rate exceeds $60 \%$ in the younger segments of the population. ${ }^{1}$ This fact is partly explained by the differences in the type of production structure of these countries -specialization in labour-intensive industries or specialization in natural resources.

\footnotetext{
I Data from the World Bank Allas (World Bank, 1997) indicate that the rate of female participation in Chile was $32 \%$ in 1995 , compared with $48 \%$ in Sweden, $46 \%$ in the United States, $45 \%$ in South Korea, $43 \%$ in England, $40 \%$ in Indonesia and Uruguay, and $37 \%$ in Colombia.
} 
TABLE 2

Chlle: Employment and average income, by type of economlc activlty and gender

\begin{tabular}{|c|c|c|c|c|c|}
\hline \multirow{3}{*}{ Type of activily } & \multicolumn{4}{|c|}{ Employment } & \multirow{3}{*}{$\begin{array}{l}\text { Incoms } \\
\text { Percentage } \\
\text { differential, } \\
\text { men/women }\end{array}$} \\
\hline & \multicolumn{2}{|c|}{ Total } & \multicolumn{2}{|c|}{ Sectoral } & \\
\hline & Men & Women & Men & Women & \\
\hline Agriculture and hunting & 18.2 & 5.6 & 87.2 & 12.8 & -21.5 \\
\hline Forestry and lumbering & 2.1 & 0.2 & 96.2 & 3.8 & 19.6 \\
\hline Fisheries & 1.7 & 0.6 & 85.4 & 14.6 & -29.6 \\
\hline Coal mining & 0.4 & - & 94.3 & 5.7 & \\
\hline Crude oil and natural gas & 0.1 & - & 97.0 & 3 & \\
\hline Metallic minerals & 2.1 & 0.3 & 94.2 & 5.8 & -14.4 \\
\hline Non-metallic minerals & 0.4 & - & 97.2 & 2.8 & \\
\hline Foodstuffs, beverages and tobacco & 3.7 & 2.6 & 74.7 & 25.3 & -36.1 \\
\hline Textiles, clothing and leather goods & 3.1 & 9.1 & 41.9 & 58.1 & -48.3 \\
\hline Wood, cork and furniture production & 2.2 & 0.6 & 87.9 & 12.1 & \\
\hline Paper products, priating and publishing & 1.2 & 0.6 & 80.1 & 19.9 & \\
\hline Chemical and related products & 1.6 & 1.2 & 73.3 & 26.7 & -14.7 \\
\hline Non-metallic mineral products and petroleum products & 0.8 & 0,4 & 80.8 & 19.2 & \\
\hline Basic iron and stecl industries & 0.5 & 0.1 & 94.5 & 5.5 & \\
\hline Metal products, machinery and equipment & 3.4 & 0.8 & 90.4 & 9.6 & -20.9 \\
\hline Other manufacturing industries & 0.5 & 0.4 & 72.5 & 27.5 & -52.4 \\
\hline Electricity, gas and steam & 0.8 & 0.1 & 92,4 & 7.6 & 30.9 \\
\hline Water works and water supply & 0.2 & 0.1 & 83.7 & 16.3 & \\
\hline Construction & 12.3 & 0.9 & 96.5 & 3.5 & \\
\hline Wholesale trade & 1.9 & 1.3 & 75.7 & 24.3 & -25.1 \\
\hline Retail trade & 11.6 & 18.2 & 57.3 & 42.7 & -28.8 \\
\hline Restaurants and hotels & 1.6 & 3.6 & 48.1 & 51.9 & 17.5 \\
\hline Transport and warehousing & 8.1 & 1.6 & 91.3 & 8.7 & 13.5 \\
\hline Communications & 1 & 0.7 & 74.9 & 25.1 & 5.7 \\
\hline Financial establishments & 1.2 & 1 & 71.3 & 28.7 & -8.5 \\
\hline Insurance & 0.5 & 0.9 & 54.6 & 45.4 & -30.9 \\
\hline Real estate and business services & 2.3 & 2.8 & 62.7 & 37.3 & -18.9 \\
\hline Public administration and defence & 3.4 & 2.2 & 76.0 & 24.0 & -11.8 \\
\hline Sanitation and related services & 0.4 & 0.5 & 63.1 & 36.9 & -64.9 \\
\hline Social and commumity services & 4.8 & 18.4 & 35.4 & 64.6 & -44.1 \\
\hline Entertainment and recreational services & 1.2 & 0.9 & 74.4 & 25.6 & -35.9 \\
\hline Personal and household services & 6.1 & 23.3 & 35.4 & 64.6 & -48.1 \\
\hline International organizations & 0.1 & 0.1 & 61.6 & 38.9 & -38.3 \\
\hline Others & 0.7 & 0.7 & 66.6 & 33.4 & 0.6 \\
\hline Tolal & 100.0 & $\mathbf{t 0 . 0 . 0}$ & & & $-20,2$ \\
\hline
\end{tabular}

Source: Prepared on the basis of CASEN 1992. The data on income corrospond to income from the main occupation.

Chilean women's place in the world of work is in a transitional stage, with a slow but rising rate of incorporation into the labour force. Their participation is very sensitive to market conditions such as levels of unemployment and wages, and this may be noted from the difference in the wage elasticities between the sexes: the elasticity of women's wages is 1.88 while in the case of men it is 1.07 . Furthermore, the changes in the supply of female labour take place through entry into or withdrawal from the labour force, whereas those of the male labour force take place through variations in the number of hours worked, with the participation in the labour force remaining more stable (Mizala, Romaguera and Henriquez, 1998).
When analysing the potential effect of free trade agreements on employment, it is important to bear in mind the high concentration of female labour in particular sectors of production, according to the data on employment and wages prepared on the basis of the National Economic and Social Profile Survey (CASEN). Chilean female employment is concentrated in agriculture $(5.6 \%)$, textiles and clothing $(9.1 \%)$, retail trade $(18.2 \%)$, social and community services (18.4\%) and personal and household services (23.3\%): in other words, five sectors of production account for $75 \%$ of total female employment (table 2).

The figures reveal that women's income is $29 \%$ below that of men, which is due to two factors: i) 
women receive lower pay in every one of the different branches of industry, and ii) they are concentrated in low-wage sectors, ${ }^{2}$ In the agricultural sector, for example, women's incomes are $21.5 \%$ below those of men, while in the textiles sector the difference amounts to $48.3 \%$, and both these sectors have a high concentration of female labour and have low average wages compared with other sectors of the economy. These figures are only an aggregate indicator of the differences in income by sex, since a more precise indicator should take account of the human capital composition of the workers. In view of the information which exists on the high level of schooling of women, however, the differences observed seem to be due both to a phenomenon of discrimination (wage discrimination and occupational segregation) and to the negative effect of discontinuous working experience. $^{3}$

The concentration of female employment in lowwage sectors may also be seen from figure 1, where the vertical axis shows the proportion of female labour and the horizontal axis shows average income. There are no observations registered in the upper right quadrant (over $50 \%$ participation in employment and high wages); most of the data are concentrated in the bottom left quadrant (less than 50\% participation in total employment and low wages). In actual fact, the only sector in which average income is high (379,351 pesos) and fernale participation is close to $40 \%$ is "international organizations": a phenomenon which may be considered as marginal, with virtually no incidence in total employment $(0.1 \%)$.

\section{The labour impacts of trade agreements}

The question of the labour impact of a potential trade agreement has been analysed for Chile by Valdes (1992), Coeymans and Larraín (1992), Muchnik and others (1992), Brown and others (1994), and Yaksic (1994). Among more general studies on the impacts of free trade agreements are those by Butelmann and Meller (eds.) (1992), Butelmann and Frohmann (1992) and Erzan and Yeats (1992). One of the few

\footnotetext{
${ }^{2}$ Extensive analyses have been made at the international level to determine whether the female labous force itself tends to depress wages in an industry, but it is not possible to examine this phenomenon with the information available for the present study.

${ }^{3}$ For more details of the rise in female participation rates in Latin America and women's high educationaj levels compared with men, see López, Pollack and Villareal (eds.), 1992; Valdes and Gomśriz (eds.), 1995, and World Bank, 1995.
}

FUGURB 1

Chlle: Average income ve. particlpatlon of women in tolal employment, by branches of activity

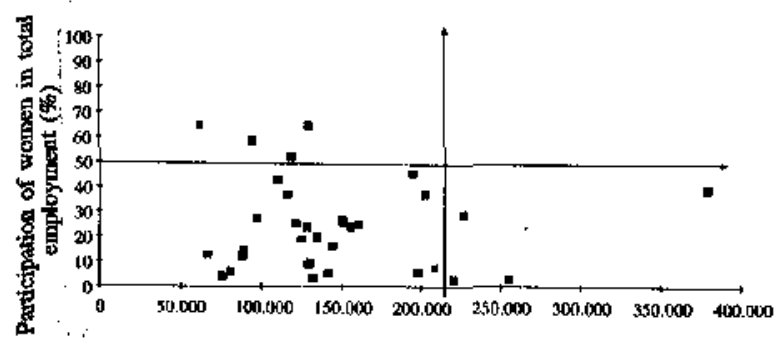

Average total monthly income (men + women) (pesos)

studies that analyses this question at the gender level is that by Joekes (1993), but this study refers to the general effects of increased trade rather than the specific effect of a free trade agreement.

The most extensively studied case is that of the possible effects of the integration of Chile into such an agreement with the United States. Generally speaking, the studies conclude that those effects would be quantitatively limited for Chile in view of the high degree of integration of the Chilean economy into the world economy and its current low tariffs.

Indeed, it is estimated that the average tariff affecting Chilean exports to the United States is only around $2 \%$, basically because the goods involved are largely natural resource-based (Butelmann and Frohmann, 1992). However, United States tariffs increase in proportion to the degree of processing of products, especially in the agricultural sector, where tariffs range from $0 \%$ to $35 \%$ (Campero and Butelmann, 1992).

On the other hand, it is estimated that the benefits of a free trade agreement for Chile will come not so much from access to markets for products with higher added value, but above all from the positive effects of greater stability of trade rules, more transparent regulations and incentives for investment in the country.

\section{a) Effects on employment and wages}

The studies on the labour impact of trade agreements have used various methodologies, including general equilibrium models, partial equilibrium models and analyses of specific sectors.

In general, the studies indicate with regard to Chile that the impact on employment and/or wages 
TABLE 3

Chilie: Effects of a fres trade agreement botweon Chlle and the Unlted States (Percentage changes)

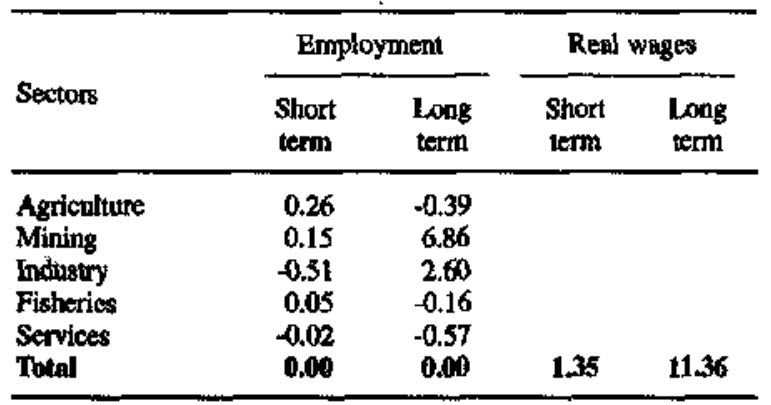

Source: Coeymans and Larrain, 1992.

would be quite low (Coeymans and Larraín, 1992; Valdes, 1992; Brown and others, 1994).

Coeymans and Larrain anticipate that the results of a free trade agreement would be a decline in employment in the short term of $0.51 \%$ in industry and $0.02 \%$ in services, which would be offset by an increase in employment in the other sectors of production (table 3). The increase in the demand for labour would be reflected in an increase of $1.35 \%$ in real wages. In the Iong term, there would be a slight reduction in employment in the agricultural, fishery and services sectors, with declines of $0.39 \%, 0.16 \%$ and $0.57 \%$ respectively, while there would be an in crease in employment in the mining and industrial sectors.

The Coeymans/Larrain model assumes that the labour force and the rate of unemployment remain constant, so that there would not be changes in employment but in real wages. This is an important restriction, since the low rates of female participation mentioned earlier give grounds for thinking that the supply of female labour is likely to increase in the future. Although the assumptions of this model limit its usefulness for the purposes of the present study, its results do serve to highlight the fact that the sectors which should "provide" labour in the long term are agriculture and services; these sectors must reduce their level of employment in order to allow growth in employment in the mining and industrial sectors.

In the article by Brown and others (1994), a general equilibrium model is developed to assess the effects of the successive incorporation of four Latin American countries into the Noth American Free Trade Agreement (NAFTA): Chile, Argentina, Colombia and Brazil. Each of the countries entering the Agreement would increase its own well-being (as
TABLE 4

Chle: Effects of a free trade agreament

(Percentage changes)

\begin{tabular}{lr}
\hline Sectors & Product \\
Tradeables & \\
Agriculture & \\
Mining & -0.2 \\
Foodstuffs & 5.2 \\
Textiles & -1.7 \\
Clothing & -6.9 \\
Leather goods & -4.3 \\
Footwear & -2.6 \\
Wood products & -0.3 \\
Furniture & -4.1 \\
Paper products & -6.1 \\
Printing & -4.3 \\
Chemicals & -1.4 \\
Petroleum products & -8.9 \\
Rubber products & 1.4 \\
Non-metallic mineral products & -7.9 \\
Glass products & -0.4 \\
Iron and steel & -9.0 \\
Non-ferrous metals & -11.7 \\
Metal products & 24.0 \\
Non-electrical machinery & -0.7 \\
Electrical machinery & -38.2 \\
Transport equipment & -17.2 \\
Miscellaneous & -81.2 \\
Non-trodeables & -6.7 \\
Gas, electricity and water & -1.3 \\
Construction & 0.9 \\
Wholesale trade & \\
Transport & \\
Financial services & 2.1 \\
Personal services & -0.6 \\
Total & -0.5 \\
\hline & -0.5 \\
& -1.1 \\
\hline
\end{tabular}

Source: Brown and others, 1994.

represented by GDP), and the well-being of each of them would also be increased by the incorporation of a new member into the agreement, except for Argentina, whose product would be reduced by the incorporation of Brazil, This model flike that of Coeymans and Larrain- assumes that aggregate employment remains constant and focuses on variations in the product and sectoral changes in employment (table 4). In Chile, because of the assumptions of the model, the effect on employment is nil, while a decline of $0.9 \%$ in wages is estimated. This decline takes place because -according to the model- NAFTA would cause a sharp concentration of production in the sectors offering comparative advantages, especially the copper mining and copper products sectors, which are capital-intensive. In contrast, it is expected that labour-intensive sectors such as clothing, leather and footwear would suffer a decline in production. 
TABLE 5

Chlle: Eflecte caused on employment by the expansion of exports and

Imports generated by a free trade agreement between

Chile and the Unlited Stales

(Number of jobs; base; 1990)

\begin{tabular}{|c|c|c|c|}
\hline Sectors & Exports & Xmports & Net effect \\
\hline Agriculture and fisheries & 1279 & 103 & 1176 \\
\hline Mining (copper and iron ore) & 17 & - & 17 \\
\hline Oil and gas & - & - & - \\
\hline Coal & - & 241 & -241 \\
\hline Other minerals & 1 & 27 & -26 \\
\hline Foodstuffs, beverages and tobacco & 1308 & 155 & 1153 \\
\hline Textiles & 257 & 409 & -152 \\
\hline Clothing & 744 & 61 & 683 \\
\hline Leather and fookwear & 275 & 17 & 258 \\
\hline Wood (excluding furniture) & 40 & 41 & .1 \\
\hline Fumitune (other than metal furniture) & 70 & 14 & 56 \\
\hline Paper & 1 & 36 & -35 \\
\hline Printing and publishing & 3 & 42 & .39 \\
\hline Chemicals and chemical products & 87 & 848 & -761 \\
\hline Petroleum refining and products & - & 11 & -11 \\
\hline Rubber products & 21 & 163 & -142 \\
\hline Plastic products & 3 & 283 & -280 \\
\hline Earthenware, pottery and glass & 134 & 144 & -10 \\
\hline Basic iron and steel industries & 1 & 126 & -125 \\
\hline Non-ferrous metals (copper) & - & 10 & -10 \\
\hline Metal proctucts & 13 & 520 & -507 \\
\hline Non-electrical machinery & 25 & 3934 & -3909 \\
\hline Electrical machinery and equipment & 7 & 881 & -874 \\
\hline Transport equipment & 23 & 483 & -460 \\
\hline Professional and optical equipment & 2 & 360 & -358 \\
\hline Other industries & 21 & 101 & -80 \\
\hline Total & $4 \mathbf{3 3 0}$ & 9010 & -4680 \\
\hline
\end{tabular}

Sounce: Valdés, 1992.

The Valdés model (1992) is a partial equilibrium model, and its results indicate that integration into a free trade agreement with the United States would lead to an increase in well-being of the order of $1 \%$ of GDP in Chile, while the impact on employment would be only small. It estimates that a maximum of 4330 jobs could be generated through the increase in exports, while a maximum of 9010 jobs could be displaced by the increase in imports, so that the net effect would be negative. In the sectors making intensive use of female labour (such as the agricultural and clothing sectors) there would be a positive effect on employment (table 5).

In addition to these studies of a global nature, sectoral studies have also been made, such as those by Muchnik and others (1992) and Yaksic (1994) for the agricultural and agroindustrial sectors; by COCHIllco (1995) for the mining sector, and by Escobar and others (1992) for the textiles sector.

The agricultural and textiles sectors have two features which are important for the purposes of this article: both of them have a significant concentration of female labour and they will suffer a relatively substantial reallocation of labour, according to the studies analysed earlier.

\section{b) The agricultural sector}

Agriculture is the sector which appears to be facing the biggest para-tariff barriers to its exports, such as quarantine requirements, marketing orders and import quotas, while processed goods of agricultural origin are subject to increasing tariffs.

The study by Muchnik and others (1992) uses a partial equilibrium model to analyse the employment situation in the agricultural and agroindustrial sectors in the event of a trade agreement between Chile and the United States. The results indicate that employment would go down by $10.4 \%$ in the case of importable agricultural goods, while it would increase in the case of both exportable agricultural goods $(2.5 \%)$ and agroindustrial goods $(28.3 \%)$. The overall effect would be an increase of $1.5 \%$ in em- 
ployment (table 6). In other words, although the net effect is small, significant reallocations would be required within the sector.

Lowering tariffs from the present level of $11 \%$ would lead to a reduction in the area planted with uncompetitive products such as wheat and oilseeds: a process which has been taking place already even without trade agreements. In the case of exportable goods, since the products currently exported are subject to relatively low tariffs or do not pay duty at all, the effects would come from the elimination of paratariff barriers; from an increase in exports of more highly processed products subject to high tariffs, such as canned goods (14\%) and prepared foodstuffs $(21 \%)$; and from the possible incorporation of products such as jam and preserved fruit, which are subject to tariffs of $20 \%$ to $35 \%$ and are basically not exported by Chile at present.

In short, the anticipated effects on the agricultural sector are: a drop in employment in the importable products sector and an expansion in exportable agroindustrial products, which are those subject to the highest tariffs in the United States.

The study by Yaksic (1994) concentrates on the qualitative impacts of a free trade agreement with the United States and gives a description of the present working conditions in the agricultural sector. First of all, it highlights the importance of seasonal labour in the agricultural and agroindustrial sectors which could be affected by free trade with the United States; according to this author, $67 \%$ of the workers in these sectors are employed on a seasonal basis. The study also highlights the importance for the agricultural sector of a parallel labour agreement and the possibility of accusations of social dumping in this context (as we shall see in section II below).

According to this study, the importance of the question of social dumping for the agricultural sector lies in the fact that situations which are not in line with the labour legislation are rife in that sector; for example, workers do not have written contracts of employment, the employers do not pay social security and health insurance contributions for them, there are problems of safety and unacceptable environmental conditions in their work, etc. The study claims that working conditions are relatively poor and that an improvement in these aspects would obviously have an impact on the costs of the sector.

On the other hand, it is noted that the mere existence of a parallel labour agreement would generate
TABLE 6

Chlle: Effects caused on agricultural and agrolndustrlal employment by a lreo trade agreement between Chłle and the Unlted States (Number of jobs and percentages)

\begin{tabular}{|c|c|c|c|}
\hline \multirow{2}{*}{ Products } & \multirow{2}{*}{$\begin{array}{l}\text { Initjal } \\
\text { employ- } \\
\text { ment }\end{array}$} & \multicolumn{2}{|c|}{ Change in employment } \\
\hline & & Jobs & $w^{a}$ \\
\hline $\begin{array}{l}\text { Importable agricultural } \\
\text { goods } \\
\text { (wheat, maize, } \\
\text { sugar beet, } \\
\text { oilseeds, etc.) }\end{array}$ & 74403 & .7709 & -10.4 \\
\hline $\begin{array}{l}\text { Exportable agricultural } \\
\text { goods } \\
\text { (fresh grapes, } \\
\text { tobacco, wine, etc.) }\end{array}$ & 79215 & 1982 & 2.5 \\
\hline $\begin{array}{l}\text { Expontable } \\
\text { agroindustrial goods } \\
\text { (tomato paste, raisins, } \\
\text { canned peaches) }\end{array}$ & 30079 & 8517 & 28.3 \\
\hline Total & 183697 & 2790 & 1.5 \\
\hline
\end{tabular}

Source: Muchnik and others, 1992.

"Percentages are with respect to initial employment.

pressures for greater compliance with the labour legislation. Thus, Yaksic asserts that, insofar as it would demand certain minimum working and wage conditions, the free trade agreement would probably result in substantial advances, including the right to collective bargaining and to participation in joint health committees.

In our view, however, it is not so clear that a parallel labour agreement would have such a strong impact on the agricultural sector. As we shall see in section II below, NAFTA-type agreements do not impose common rules on the various countries but basically merely oblige each country to comply with its own labour legislation.

\section{c) The textiles sector}

In the textiles sector, the tariff structure affecting Chilean exports is also highly progressive, depending on the added value of the product, so that the effective protection is probably greater than might be suggested by the present tariffs. Moreover, there have also been other forms of protection for the United States textile industry, ranging from anti-dumping measures to countervailing duties.

The studies which have been made so far emphasize how difficult it is to predict the future evolution of the sector, which is highly conpetitive, subject to rapid and constant technological progress, and does not enjoy intrinsic competitive advantages 
TABLF 7

Chile: Summary of effects on employment of a free trade agreement, according to various studies

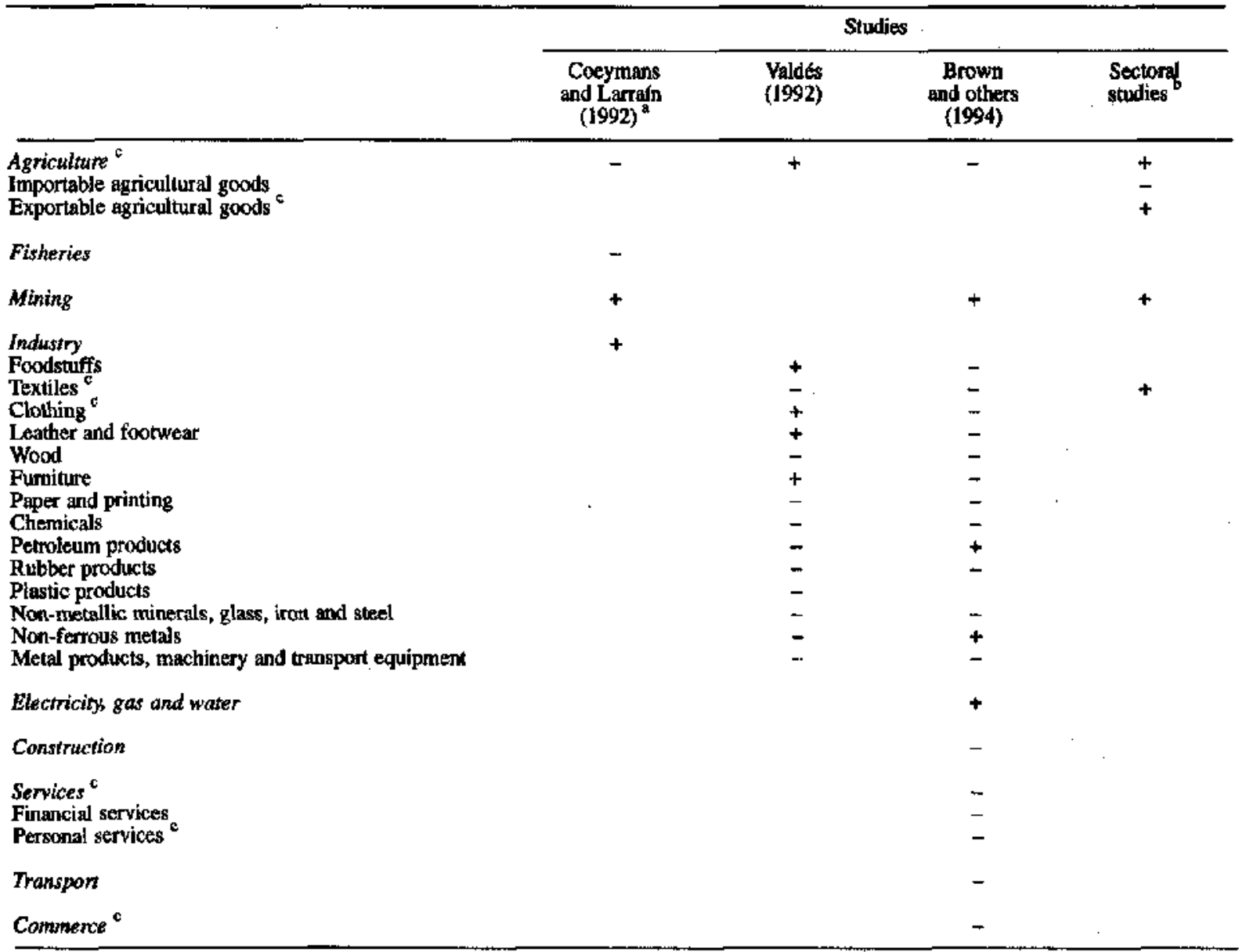

This study deals with the long-term effects.

${ }^{6}$ Correspond to studies by Muchnik and others (1992) for the agricultural sector and Escobar and others (1992) for the textile sector.

${ }^{c}$ Seclors or branches where there is a major share of fomale labour.

in the case of Chile. According to Escobar and others (1992), a free trade agreement would speed up the process of technological modernization of the textiles sector and lead to a slight increase in imports and a somewhat larger increase in exports, so that the sector would grow faster than if there were no agreement and the current decline in employment in it would be checked to some extent.

\section{d) Summary of sectoral impacts}

By way of summarizing the foregoing analysis, a list is given below of the sectors which would be affected by an integration agreement, indicating whether the expected effect on employment is positive or negative and noting the sectors where there is a high proportion of fernale labour (table 7).
In general, the studies conclude that a sectoral reallocation of employment would be needed, and they expect that a free trade agreement would have a positive effect on wage levels. The studies which use equilibrium models tend to predict a lower growth rate of employment in the activities where female labour is currently concentrated. A positive impact on employment in mining is expected and a negative impact on employment in service activities, while the expected effect in the areas of agriculture and industry is varied and depends to a large extent on the degree of disaggregation of the analysis.

There are studies on the agricultural sector which highlight the potential positive and negative impacts of the agreements. As the female labour force is mostly in export agriculture and agroindustry, however, the 
net effect for this labour force could be more positive than is indicated by the global analyses.

In the case of textiles, the three empirical studies found that there would be a negative impact, while the study of a more qualitative nature estimated that a free trade agreement would ease the negative tendency which the sector has been displaying. In this sense, the tendencies of both the textile and clothing sectors are uncertain, and a process of labour reconversion will probably be needed within the various subsectors of the textile industry.

From the gender point of view, there are two issues which it would be important to take into account in future research. Firstly, the fact that the main labour impact of a free trade agreement is reflected in wage increases is the natural result of the fact that most of the studies assume that the labour force remains constant. However, the incorporation of women into the labour force is precisely the most important potential source of employment growth in Chile, and the increase in the supply of labour is obviously a factor which will moderate the growth of real wages.

Secondly, sectoral employment is heterogeneous not only in terms of skills but also in terms of gender. Thus, assuming full mobility from the sectors which dispensed with workers into the sectors which should absorb them also means assuming that women working in the services sector can be absorbed by the industrial and mining sectors, which is highly improbable in view of the prevailing occupational segregation by gender.

Consequently, it is necessary to progress towards studies with a higher degree of disaggregation at both the sectoral and the gender level. Studies which take into account the fact that the labour force is heterogeneous and that mobility is not perfect will give a better idea of the wage impact of sectoral reallocation due to an integration agreement than the models applied so far.

\section{Some congequences for female employment}

Female employment is highly concentrated in certain sectors of production, and many of these appear to be sensitive to the impact of a potential free trade agreement. This would be the case, in particular, in the agricultural, agroindustrial, textiles and clothing sectors, although there are branches within each sector where employment levels could either rise or fall.
Although the information on the impact of an integration agreement on the labour situation of women is still somewhat unreliable, this exploratory study seeks to highlight three factors which would affect the result:

i) It is expected that a free trade agreement will have a significant impact on the agricultural, agroindustrial, textile and clothing sectors. Because of the high concentration of female labour in these sectors and the fact that the diversification of the pattern of women's employment seems to be a slow business, what happens in these sectors will naturally influence the female labour situation. Moreover, within each of these sectors there are subsectors which could be either benefited or adversely affected by integration, with the effects being negative in the case of the more traditional or technologically backward activities.

ii) The effect of free trade agreements on the services sector is very important, because this sector employs a great deal of female labour. The studies which have been made consider that this sector will have to reduce its level of employment so that the surplus workers can be absorbed by the expanding sectors. The differences between production activities in terms of their composition by gender, however, leads us to believe that the intersectoral mobility of labour will be lower than assumed in the studies made so far. One of the criticisms levelled at this type of analysis is that it underestimates the new production niches or opportunities created by trade. It could be held that there has been a tendency to overlook the fact that the growing integration of the Chilean economy as a supplier of services to the rest of Latin America -in such areas as financial activities, insurance, computation, etc.- could have a positive effect on female employment.

iii) At the same time, economic growth will naturally help to expand the employment opportunities of women. In view of their current rather low rates of participation in the labour force, the main source of growth of employment will be women, unless there are massive phenomena of international migration or the incorporation of part-time young workers or there is a very intensive process of technification.

Finally, the greater intemational integration that accompanies trade agreements, the closer links with countries which have made more progress in improving the relative situation of women, and the very fact that the agreements address such issues as discrimination against women should also be positive demonstration factors in the case of Chile. 


\section{II}

\section{Free trade agreements and labour}

\section{legislation affecting women}

\section{What do the agreements say with regard to women?}

In general, the actual texts of the agreements signed by Chile do not make any explicit reference to women. So far, the only agreement which has specifically included this matter is the labour cooperation agreement annexed to the free trade agreement with Canada, ${ }^{4}$ which basically follows the NAFTA model.

When the NAFTA negotiations began in 1990, the prevailing view was that trade agreements should only deal with matters of trade and investment and should not include social, labour or environmental matters. However, pressures by trade unions and nongovernmental organizations, together with the victory of the Democratic candidate Bill Clinton in the 1992 Presidential elections, led to the preparation of two supplementary agreements, one on environmental matters and the other on labour matters.

Women are referred to, although only indirectly, in the supplementary agreement on labour matters signed by Canada," the United States and Mexico as an annex to NAFTA; this supplementary agreement mentions gender-based matters in two of the 11 guiding principles which the three countries undertake to promote, subject to the national legislation of each country, but without laying down minimum common standards. These two principles are the elimination of discrimination in employment on account of race, religion, age, sex or other reasons, and equal pay for men and women (according to the principle of equal pay for equal work in the same establishment). These concepts are only general principles, and failure to comply with them does not involve any direct trade sanctions.

\footnotetext{
${ }^{4}$ Labour Cooperation Agreement between the Govemment of the Republic of Chile and the Government of Canada.

${ }^{5}$ It is interesting to note that in the case of Canada more women were against the free trade agreement between Canada and the United States (only $44 \%$ were in favour) than in the case of men (60\% in favour). See Gidenhil, 1995.
}

The agreement seeks above all to ensure compliance with the respective national legislation; the machinery for appealing to the Trinational Labour Commission and setting up expert assessment committees is extremely unwieldy and hard to implement.

Rather than using supranational norms or standards based on universally recognized principles, such as the ILo conventions, for example, the United States has promoted the concept of compliance with the labour legislation of the respective countries.

In the event of Chile's accession to NAFTA, it seems unlikely that the country's prevailing rules on women workers will be at variance with the general principles contained in the provisions of NAFTA. If there were a trade dispute or a conflict of a political nature, however, the gap which still exists in Chile between the legislation and its practical application in the case of some labour rights of women could be brought up by the other members of NAFTA. ${ }^{6}$

There are also differences of approach between the Chilean and United States rules on female labour. Thus, for example, the legislation which exists in Chile for the protection of women -the most obvious case is protection of working mothers- does not exist in the same form in the United States legislation, while on the other hand Chile does not have the legal mechanisms that exist in North America for taking legal action against an employer in cases of discrimination.

In the European Union, many instruments have indeed been developed for the promotion and special training of women; the legislation on equality of opportunities is impressive, ${ }^{7}$ but the levels of implementation still leave much to be desired. ${ }^{8}$ In the other examples of integration (MERCOSUR, Andean Pact,

\footnotetext{
6 With regard to working conditions in some export sectors, see Mizala and Romaguera; 1997.

7 See Nielsen and Szyszczaik (1991), Prechal and Burrows (1990) and Blanpain (1991).

8 This is shown by the statistics (European Union, EUROSTAT, 1992) and also by the most qualitative analyses (Coyle, 1995).
} 
CARICOM, Central American Common Market) the gender dimension is almost completely absent, although there have been moves by some social actors, especially those connected with women's movements, to raise this issue.

\section{The debete on social dumping}

One of the issues which has come up again recently in connection with free trade is the effect of differences in wage levels, social security, and workers' protection and safety between trading partners with different economies and economic and social conditions.

For some anthors, and above all for the workers in the most highly developed countries, this would amount to "social dumping", an unfair trade practice and a kind of subsidy for producers, since it would increase the competitive advantages of the less developed partner due to the lower cost of the labour factor and "over-exploitation" of workers, while it would also encourage capital flight by offering lower labour costs to producers from the developed countries themselves.

A classic example which has been mentioned as an illustration of this type of situation is that of the in-bond assembly operations in the northern border areas of Mexico, where Mexican workers (especially female workers) with low levels of skilts, low wages and unsatisfactory working conditions assemble components and carry out simple processing operations on inputs brought in from the United States in order to manufacture final goods for re-export to that market.

This line of argument has been used on innumerable occasions by United States trade unions and also by candidate Ross Perot in the 1992 Presidential campaign (Doherty, 1992). Indeed, the Generalized System of Preferences and the United States Super 301 Intenational Trade Act include measures providing for unilateral protection against this kind of situation. The concept of social dumping has also been used to explain the deterioration in labour conditions in the developed countries as a result of a kind of "race to the bottom" (see Kapstein, 1997). These arguments, which were already being put forward with regard to the traditional kinds of trading partners (especially from Southeast Asia and Latin America), were expressed much more forcibly in the debate on NAFTA when a free trade agreement was being negotiated with Mexico.
The question of the problems caused by the integration of economies of markedly different types also arose in the course of the formation of the European Economic Community, and in fact when Spain and Portugal -telatively less developed countries- were incorporated into the EEC special measures were taken to deal with this problem. Labour and social standards had to be officially approved and financial support was given in order to form a commion labour market.

We nevertheless consider that the arguments questioning the concept of social dumping are quite convincing (ILO, 1994; Alburquerque, 1994):

i) The accusation of social dumping involves an intrinsic error, since dumping means the placing of products on foreign markets "at less than the normal value of the products" (article VI of GATT). The "normal value" is generally defined in terms of the value on the domestic market, and consequently it would not be possible to speak of dumping if a product is exported at a value corresponding to its domestic cost.

ii) Differences in labour costs frequently reflect differences in levels of productivity between different countries.

iii) The quality of life of workers has a positive effect on levels of productivity, and there is a virtuous circle between quality of life and productivity which favours the international competitiveness of the economy in question.

iv) Although in the short term disparities in labour costs may be very great, free trade makes it possible in the medium and long term, with increasingly integrated economies, for the wage levels of the relatively less developed country to draw closer to those of the more highly developed countries.

v) The interests of workers in countries with unequal levels of economic and social development do not necessarily coincide, and the argument of social dumping is often used as a means of protectionism by developed countries which fear foreign competition and capital flight.

The images and associations of social dumping which are put forward, especially in the press of the developed countries, often depict a situation where female workers, with low wages and no social security, take the place of workers with good jobs in a developed country. There are no solid proofs which back up this allegation, however, and in view of the occupational segregation affecting women it is highly unlikely that such a situation would exist. 
The validity of the social dumping argument, including its gender dimensions, is thus quite doubtful, and it would appear to be necessary to explore other ways of analysing and, in time, regulating the effects of international trade liberalization and economic integration processes on workers.

\section{III}

\section{Instruments for regulating the labour}

\section{and social Impact of Integration}

Chile is seeking to establish free trade arrangements with NAFTA, the European Union, the member countries of the Asia-Pacific Economic Cooperation Forum (APEC) and the Western Hemisphere, and it is very probable that labour issues will be included in some way in some of these negotiations. What, then, should be the mechanisms to be adopted for establishing and supervising the labour standards governing these agreements?

In the industrialized countries, the insistence on supranational labour standards is often due more to defensive considerations than to a vocation of international solidarity. This attitude has grown stronger as trade liberalization and globalization have gradually eliminated other more traditional protective barriers, such as tariffs and para-tariff mechanisms.

In the developing countries, which ane interested in the inflow of foreign investments and the stimulation of their external sector, this matter is viewed rather ambiguously. On the one hand, some sectors are interested in taking advantage of the situation provided by the negotiation of trade agreements in order to raise national labour standards. On the other hand, there is a feeling in governments and among employers that the establishment of supranational standards could mean the introduction of protectionist mechanisms, promoted by the industrialized countries, which would adversely affect development.

This variety of approaches was reflected recently in the Singapore Declaration of the Meeting of Ministers of Trade of the World Trade Organization (wTO) in December 1996, at which it was agreed that the ILO should be the organization responsible for promoting compliance with basic labour standards, thus avoiding, at least for the present, the inclusion of this issue on the agenda of the WTO. In spite of the resistance of many developing countries, however, it seems clear that social and labour issues, and their linkages with international trade, have already become a part of the international agenda.

It is in the interests of a developing country like Chile to address and study these issues to avoid their being used as an instrument of protectionism, rather than refusing to consider them at all. Furthermore, it is important to take them into account in order to give social and political legitimacy to the agreements.

The question of gender has been largely absent from this debate until very recently. There had been some mention of women, as a particularly vulnerable and discriminated group, and it had been noted that there was a need for special protection -above all for working mothers- as well as for some special training and promotion measures. It is only recently that this protective and rather paternalistic view has begun to be replaced by a new approach based on the concept of gender, in which equality of opportunities for both men and women and the elimination of the social and cultural barriers which prevent this have moved into the spotlight. This perspective is not easy to incorporate in the traditional trade union and la. bour demands. Some pioneering efforts have come from countries where equal opportunity plans have been put into effect and from the work of the ILO in this field. ${ }^{9}$

The basic starting-point is provided by the Conventions of the 1LO; the international organization specially created to deal with these matters. Moreover, the ILO's tripartite method of operation and of consensus-seeking -workers, employers and governments are all represented in its assemblies- provides a guarantee that the interests of all sectors will be represented.

\footnotetext{
${ }^{9}$ See Ulshoefer (1994) and other ILOO studies cited therein.
} 
In this respect, it has been suggested that there are some basic intemational standards -embodied in the ILO's Conventions- which may be considered as prior requisites if trade is to be able to contribute to improvernents in the living conditions of workers (Adarny, 1994): Convention 87, on freedom of association; Convention 98 , on the right to organize and collective bargaining; Convention 135 , on the protection of workers' representatives; Conventions 29 and 105 , on the elimination of forced labour; Convention 138, on the prohibition of child labour; Convention 111 on the prohibition of discrimination in employ. ment; and Convention 100 , on equal remuneration for men and women for equal work.

These Conventions have been ratified by most of the countries in the world and their principles enjoy at the very least considerable intemational legitimacy. Nevertheless, there are also different views on what these basic international standards and the mechanisms for implementing them should be. ${ }^{10}$

The use of these Conventions as basic rules for international trade is not as simple as it might at first appear. The Conventions and procedures of the ILO do not enjoy the same acceptance and political legitimacy in all countries. There are some countries, some of them with great weight in the international concert, which consider labour legislation as a strictly domestic matter of national sovereignty.

The United States, for example, has ratified only 11 of the 174 Conventions in the 60 years between 1934 and 1994. Most of the Conventions ratified are of minor importance, and several of them deal with technical matters. The United States has not ratified such fundamental Conventions as No. 87 (freedom of association) and No. 98 (right to collective bargaining), even though its own legislation provides for those rights (Cowie and French, 1994). In some cases, Conventions are not signed or ratified because the countries do not recognize certain rights (this is very evident, for example, in the United States, in the case of protection of working mothers and matemity leave). Generally speaking, however, what is involved is a different philosophy regarding the estab. lishment of general rules; a reluctance to enter into the supranational labour regulations developed within the ILO; and a view that these mechanisms are too bureaucratic, unwieldy and not in keeping with specific national conditions.

10 See French (1996), Freeman (1996), Golub (1997) and Langille (t997).
In the case of the United States, instead of supranational rules based on universally recognized principles, the government has promoted the concept of compliance with national labour legislation in the respective countries with which it has trade agree. ments. This is based on the principle that the national legislation best reflects the level of development of labour rights and the special conditions of each country, and that it is the disparities between labour rules and actual practice that should disappear. Insofar as trade agreements cause the labour practices of each country to be studied in greater detail, this should at the same time promote a higher level of control and supervision and the elimination of those disparities in the field of labour rights.

In the case of the European Community -later the European Union- initiatives such as the 1974 and 1984 Social Action Programmes, the establishment of the Eumopean Social Fund, and the Maastricht Treaty were designed to level out and consolidate the social policies of the member countries, some of which were fairly backwand in this respect. The balances being drawn up in the $1990 \mathrm{~s}$, however, indicate that social advances have not been as rapid as economic progress. The promotion of social policies in each country would appear to be connected more with the needs arising from the consolidation of the great European market than with the application of binding Community standards (Santillán, 1995).

In the Community instruments, women form part of a long list of vulnerable and discriminated sectors of society with regand to which special policies need to be developed. Some general instruments have been established for creating greater equality of opportunity (Weinberg, 1992), but the scanty changes which have taken place in female employment and the maintenance of the wage gap between men and women (European Union, EUROSTAT, 1992), at least in the 1980s, would appear to indicate that it has not yet been possible to promote significant changes.

The European Social Charter has been seen as a model mechanism for regulating the labour and social impacts of integration. It is important to bear in mind, however, that several of these mechanisms have been promoted mainly by the most solid and prosperous Welfare States. Although it is important to learn from the European experience, it would appear to be very difficult to imitate it.

We believe that there is no reason why gender issues should be caught up in this debate. They are 
based on a different concept -equality of opportunities between men and women-, which means that rather than putting forward a set of demands (although they do also include specific demands) the real aim is to do away with the social and cultural mechanisms which cause and reproduce discrimination. In the case of the issues connected with motherhood, for example, it is not just a question

\section{IV}

\section{Final comments}

The debate on the labour effects of integration agreements and, in particular, their effects on the female labour market is still at an incipient stage (see Yáfiez and Todaro, 1997).

In Chile, women's participation in the labour market is growing but is still quite low by international standards, while female employment is concentrated in certain sectors of production.

The estimates made using different models to analyse the labour effects of a potential free trade agreement in the case of Chile indicate that the net effect in terms of employment and wages would be quite small. In general, the studies made so far have not taken into account the gender dimension, which is important for at least two reasons: firstly, although the net effects may be quite small, it is anticipated that it will be necessary to reallocate employment between production sectors which have very different employment structures by gender. Secondly, some of the sectors which are most sensitive to a free trade agreement are those where much of female employment is concentrated.

In this sense, the changes in the employment demands of the different sectors due to integration processes would represent a major challenge for female integration into the labour force, since they would have to run counter to the tendency towards segregated occupations currently displayed by the Chilean economy.

At the same time, it is expected that regional integration, links with countries where the relative situation of women is better, and the fact that the agreements include some gender considerations may also be positive demonstration factors for developing countries like Chile. of obtaining more day nurseries and better maternity leave, but of securing the recognition of social responsibility for the upbringing of children, which should be reflected, among other things, in parent leave. In order to achieve these purposes, both the pragmatic Anglo-Saxon concept and the more principle-oriented approach based on international labour standards are valid means.
Although women's issues have been present in some trade agreements, they have been dealt with in a relatively indirect manner. In the agreement between the United States, Mexico and Canada, the guiding principles include non-discrimination in employment and equal pay for equal work between the sexes, although failure to comply with these principles does not involve direct trade sanctions. The agreements do not seek to establish supranational regulations or standards but basically merely to ensure compliance with the respective national legislation.

If Chile enters NAFTA, it seems unlikely that the prevailing Chilean rules will be at variance with the general principles of that agreement, although the gap which exists in Chile between the legislation and its practical application in the case of some labour rights of women could be brought up as an issue by developed countries.

It is precisely the developed countries which have been responsible for accusations that some developing countries are guilty of possible social dumping, because of the differences in working conditions and legislation.

Although there do not seem to be any solid arguments behind these allegations, the developing countries must realize that the linking of economic integration matters with their labour effects has become a part of the international agenda, and it would be preferable to address this question in order to avoid it being used as an instrument of protection, rather than refusing to consider it at all.

With regard to specific gender issues, it must be acknowledged that there is very little infornution for evaluating the differential effect of economic integra- 
tion. At the same time, in order to secure a positive impact on the situation and rights of women workers, the discussion must be taken away from matters involving specific demands, and it is also necessary to get away from the habit of viewing women merely as a vulnerable group requiring special protection. In this respect, it is important to emphasize the principle of equality of opportunities in the international debate, because this will make it possible to gradually eliminate the mechanisms that reproduce discrimination. Likewise, it seems necessary that each country's legislation, rather than emphasizing and expanding the labour rights of working mothers, should try to secure more general acceptance of the concept of parental rights.
Finally, a great deal of attention has been given to the question of integration seen as a threat (from the point of view of social dumping), but in fact integration also presents challenges and opportunities for the world of female labour, including not only the challenge of breaking the occupational/sectoral segregation of female employment in a situation of reallocation of employment, but also the demonstration effect deriving from integration with countries which display greater relative progress in gender matters and the effect that can be exerted by the mere fact that the agreements may include general principles relating to non-discrimination and equality of opportunities.

(Original; Spanish)

\section{Bibliography}

Adamy; W. (1994): Intemational trade and social standards, Intereconomics, vol. 29, No. 6, Baden-Baden, Nomos.

Alburquerque, M. (1994): Implicancias del factor laboral en un eventual Tratado de Libre Comercio con Estados Unidos, Papeles de Trabajo-PEP, No. 43, Santiago, Chile, Corporación Tiempo 2000, November.

Blanpain, R. (1991): Labour Law and Industrial Relations of the European Community, Deventer, Netherlands, Kluwer Law Intersational.

Brown, D. K. and others (1994): An Assessment of $E x$ tending NAFTA to Other Major Trading Countries in South America, Washington, D.C., Inter-American Development Bank (IDB)/ Economic Commission for Latin America and the Caribbean (ECLAC), February.

Butelmann, A and A. Frohmann (1992): Hacia un acuerdo de libre comercio entre Chile y Estados Unidos, $R e$ laciones economicas internacionales Chile/EE.UU., No. 3, Santiago, Chile, CIEPLAN, February.

Butelmann, A. and P. Mellex (eds.) (1992): Estrategia comercial chilena para la década del 90 : elementos para el debate, Santiago, Chile, CIEPLAN.

Campero, M. P. and A. Butelmann (1992): Medición del escalonamiento arancelario de las exportaciones chilenas a los EE.UU, in A. Butelmann and P. Meller (eds.), Estrategia comercial chilena para la decada del 90: elementos para el debate, Santiago, Chile, CIEPLAN.

COCHILCO (Chilean Copper Commission) (1995): Impactos del NAFTA y MERCOSUR en las exportaciones y el empleo del sector minero. Santiago, Chile, Departamento de Estudios Generales, June.
Coeymans, J. E. and F. Larrafn (1992): Impacto de un acuerdo de libre comercio entre Chile y los Estados Unidos: un enfoque de equilibrio general, Confederación de la Producción y del Comercio: Tratado de Libre Comercio enste Chile y Estados Unidos, Santiago, Chile, Confederation of Production and Commence.

Cowie, J. and J. D. French (1994): NAFTA's labor side accord: A textual analysis, Latin American Labor News, No. 9, Florida, Florida International University.

Coyle, A. (1995): The European Union and equal opportunities for women, Seminar on Women and MERcosUR, Santiago, Chile, Latin American Faculty of Social Sciences (ELACSO), mimeo.

Doherty, W. (1992): El intercambio comercial en el continente americano. Analisis y reaccion de los sindicatos, Washington, D.C., American Institute for Free Labour Development (AIFLD), May.

Erzan, R. and A. Yeats (1992): Free Trade Agreements with the United States: What's in it for Latin America?, Policy Research Working Papers, No. 827, Washington, D. C., World Bank.

Escobar, L. and others (1992): Efectos esperados de un ALC con los Estados Unidos en los sectores textil, confecciones, cuero y calzado, Santiago, Chile, Confederation of Production and Commerce.

European Union, BUROSTAT (Statistical Office) (1992): Les fenmes dans la Communauté Europeénne, Brussels.

Freeman, R. B (1996): International labor standards and world trade: Friends or foes, in J. Schott (ed.), The 
World Trading System: Challenges Ahead, Washington, D. C., Institute for International Economics (IIE).

French, J. D. (1996): A busca de padröes de directos trabalhistas no comercio internacional, Estudos avançados, vol. 10, No. 27, Så Paulo, Brazil.

Gidenhil, E. (1995): Economic man-social woman? The case of the gender gap in support for the Canadan United States Free Trade Agreement, Comparative Political Studies, vol. 28, No, 3.

Golub, S. (1997): Are intemational labor standards needed to prevent social dumping?, Finance and Development, vol. 34, No. 4, Washington, D. C., International Monetary Fund (IMF)/World Bank

INE (National Institute of Statistics) (several years): $E_{n-}$ cuesta del trimestre octubre-diciembre, Santiago, Chile.

ILO (1994): Working party on the social dimensions of the liberalization of international trade, The Social Dimensions of the Liberalization of World Trade, Geneva, November.

Joekes, S. (1993): The Influence of International Trade Expansion on Women's Work, International Labour Organisation (ILO), Interdepartmental Project on Equality For Women in Employment, Geneva, November.

Kapstein, E. B. (1997): Racing to the bottom? Regulating international labor standards, Intemationale Politik und Gesellschaft, No. 2.

Langille, B. A. (1997): Eight ways to think about international labour standards, Joumal of World Trade, vol. 31, No. 4, Geneva, Kluwer Law International.

Lopez, C., M. Pollack and M. Villareal (eds.) (1992): Género y mercado de trabajo en América Latina, Santiago, Chile, Regional Employment Programme for Latin America and the Caribbean (PRBALC)/ILO.

Mizala, A. and P. Romaguera (1996): Flexibilidad laboral y mercado del trabajo en Chile, Colección Estudios CIEPLAN, No, 43, Santiago, Chile, CIEPLAN.

(1997): Estándares laborales y protección potencial ¿Amenazas para Chile?, in R. Fischer (ed), Las nuevas caras del proteccionismo, Santiago, Chile, Dolmen-CEA.

Mizala, A., P. Romaguera and P. Henriquez (1998): Oferta laboral y seguro de desempleo; estimaciones para la economía chilena, Documento de Trabajo, No. 28, Centro de Economía Aplicada (CEA), Santiago, Chile, University of Chile.

Muchnik, E. and others (1992): Efectos esperados de un ALC con los Estados Unidos en los sectores agropecuario y agroindustrial chilenos, Santiago, Chile, Confederation of Production and Commerce.

Nielsen, R. and E. Szyszczak (1991): The Social Dimension of the European Community, Copenhagen, Handelshojskdlens Verlag.

Prechal, S. and N. Burrows (1990): Gender Discrimination Law of the European Community, Worcester, Dartunouth Publishing Company.

Santillán, S. (1995): Los mercados laborales: perdidas y ganancias en el proceso de integración, paper presented at the Seminar on the Social Dimension of Regional Integration, Santiago, Chile, European Union/Rio Group. Training Centre for Regional Integration (CEFIR).

Ulshoefer, P. (1994): Igualdad de opornunidades para las mujeres en los años 90: desaffos para la legislación del trabajo, la seguridad social y las relaciones laborales, Santiago, Chile, ILO.

Valdés, R. (1992): Una metodologia para evaluar el impacto cuantitativo de uns liberalización comercial: aplicación al ALC entre Chile y ER.UU., in A. Butelmann and P. Meller (eds.), Estrategia comercial chilena para la decada del 90: elementos para el debate, Santiago, Chile, CIEPLAN.

Valdés, T. and E. Gomáriz (eds.) (1995): Mujeres latinoamericanas en cifras. Tomo comparativo, Santiago, Chile, Instituto de la Mujer, Latin American Faculty of Social Sciences (FACSO)

Weinberg, P. D. (ed.) (1992): Integración y formación. Lecciones de la experiencia comunitaria europea y las perspectivas para el MERCOSUR, Montevideo, Ministerio de Trabajo y Asuntos Sociales (España)/ ILO, Inter-American Research and Documentation Centre on Vocational Training (CINTERFOR).

World Bank (1995): Labour and economic reforms in Latin America and the Caribbean, World Development Report 1995: Regional Perspectives, Washington, D. C., June.

(1997): Atlas 1997, Washington, D. C.

Yaksic, A. (1994): TLC con USA y sus impactos posibles en los trabajadores temporeros agricolas, Santiago, Chile, May, mimeo.

Yaffez, S. and R. Todaro (1997): Globalización, reestructuración competitiva y empleo femenino en Chile, in S. Yáfez and R. Todaro (eds.), Sobre mujeres y globalizacion, Santiago, Chile, Centro de Estudios de ia Mujer (CEM). 